\title{
Early estimates of seasonal influenza vaccine effectiveness in Europe among target groups for vaccination: results from the I-MOVE multicentre case-control study, 2011/12
}

E Kissling (e.kissling@epiconcept.fr) ${ }^{1}$, M Valenciano $^{1}$, I-MOVE case-control studies team ${ }^{2}$

1. EpiConcept, Paris, France

2. Members of the team are listed at the end of the article

Citation style for this article:

Kissling E, Valenciano M, I-MOVE case-control studies team. Early estimates of seasonal influenza vaccine effectiveness in Europe among target groups for vaccination: results from the I-MOVE multicentre case-control study, 2011/12. Euro Surveill. 2012;17(15):pii=20146. Available online: http://www.eurosurveillance. org/ViewArticle.aspx?Articleld $=20146$

Article submitted on 3 April 2012/ published on 12 April 2012

To provide an early estimate of $2011 / 12$ influenza vaccine effectiveness (VE), we conducted a multicentre case-control study based on seven sentinel surveillance networks. We included influenza-like illness cases up to week 7/2012 from the vaccination target groups, swabbed less than eight days after symptom onset. Laboratory-confirmed influenza $\mathrm{A}\left(\mathrm{H}_{3}\right)$ cases were compared to negative controls. Adjusted VE was $43 \%$ ( $95 \%$ confidence interval: -0.4 to 67.7 ), suggesting low to moderate VE against influenza $\mathrm{A}\left(\mathrm{H}_{3}\right)$ in the early 2011/12 season.

\section{Introduction}

In the context of the Influenza Monitoring Vaccine Effectiveness in Europe (I-MOVE) Network we estimated the effectiveness of the 2011/12 trivalent vaccine against medically attended influenza-like illness (ILI) that was laboratory-confirmed as influenza. We undertook a multicentre case-control study based on the European Influenza Sentinel Practitioner Surveillance Networks (EISN) [1] from eight study sites (France, Hungary, Ireland, Italy, Poland, Portugal, Romania and Spain).

Data were collected from week 48/2011 to week 7/2012. During these 12 weeks of data collection, 867 (92.7\%) of 935 laboratory-confirmed influenza cases recruited in the study were identified as influenza $A\left(\mathrm{H}_{3}\right)$. This finding was consistent with data from the Community Network of Reference Laboratories (CNRL) for Human Influenza in Europe: of the 11,159 viruses detected from week 40/2011 to week 7/2012, 95.9\% were influenza type $A$, and of 6,238 influenza $A$ viruses subtyped, $97.5 \%$ were influenza $A\left(\mathrm{H}_{3}\right)$ [2].

We provide early season estimates of the effectiveness of the 2011/12 vaccine against influenza $\mathrm{A}\left(\mathrm{H}_{3}\right)$ virus among those subpopulations identified as target groups for vaccination in the respective countries (Table 1) [3-10].

\section{Methods}

The study population consisted of non-institutionalised patients of all ages (over the age of 17 years in Hungary) consulting a participating practitioner for ILI and having a naso-pharyngeal swab taken less than eight days after symptom onset. Recruitment of ILI patients was based on exhaustive (Romania), systematic (Hungary, Ireland, Italy, Poland, Portugal, Spain) or quota sampling (France) [11]. The European Union case definition for ILI was used: sudden onset of symptoms, at least one of these four systemic symptoms (fever or feverishness, malaise, headache, myalgia) and at least one of these three respiratory symptoms (cough, sore throat, shortness of breath) [12]. A case of confirmed influenza $\mathrm{A}\left(\mathrm{H}_{3}\right)$ was an ILI patient who was swabbed and tested positive for influenza $\mathrm{A}\left(\mathrm{H}_{3}\right)$ virus using RT- PCR or culture. Controls were ILI patients who tested negative for any influenza virus.

Individuals were considered vaccinated if they had received a dose of the 2011/12 seasonal vaccine more than 14 days before the date of onset of ILI symptoms, and unvaccinated if they had received no vaccine or the vaccine was given less than 15 days before the onset of ILI symptoms. The variables collected during this season were the same as in 2010/11 [13], except for pandemic vaccination (not collected in 2011/12) and smoking (not collected in France). In each country we included ILI patients who presented to the practitioner up to the end of week 7/2012 who belonged to a target group for vaccination, with onset of symptoms more than 14 days after the start of national or regional influenza vaccination campaigns. For each study site, we excluded controls with symptom onset in the weeks before symptom onset of the first influenza $\mathrm{A}\left(\mathrm{H}_{3}\right)$ case, as well as cases infected with any non- $\mathrm{A}\left(\mathrm{H}_{3}\right)$ influenza virus.

We conducted a complete case analysis excluding individuals with missing values. We estimated the pooled 


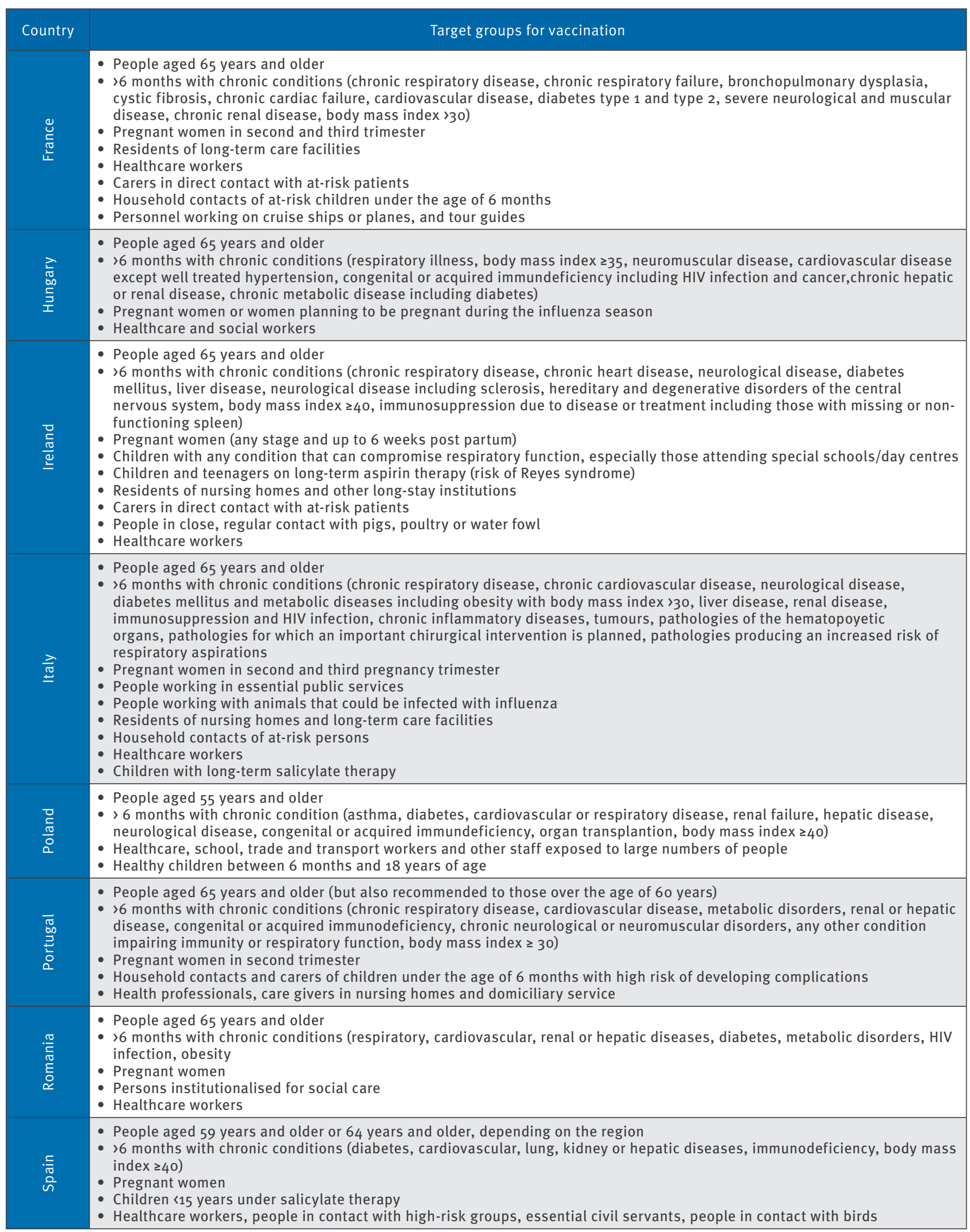


seasonal influenza vaccine effectiveness (VE) as 1 minus the odds ratio (OR) expressed as a percentage, using a one-stage method with the study site as fixed effect in the model.

To estimate adjusted VE, we used logistic regression models including the following potential confounding factors: age groups (10-year age bands), sex, week of symptom onset, chronic disease (at least one), hospitalisations associated with a chronic disease in the last 12 months, and number of visits to a general practitioner or paediatrician in the last 12 months.

\section{Results}

Among the 1,056 practitioners who agreed to participate, 528 (50\%) recruited at least one ILI case (Table 2).

Of the 2,090 ILI cases recruited, 575 belonged to a target group for vaccination. After excluding the weeks before symptom onset of the first influenza $\mathrm{A}\left(\mathrm{H}_{3}\right)$ case at each of the study sites and 10 cases positive for other influenza viruses, we included 208 influenza $A\left(\mathrm{H}_{3}\right)$ cases and 330 influenza-negative controls (Figure). Poland is not included in this preliminary analysis as no influenza $\mathrm{A}\left(\mathrm{H}_{3}\right)$ case was detected.

The first study site to recruit an influenza $A\left(\mathrm{H}_{3}\right)$ case in the target group for vaccination was Italy (week 48/2011), and the last sites were France, Romania and Spain (week 52/2011) (Table 2). The median number of weeks during which patients were recruited for the preliminary analysis was nine, ranging from six in France to 12 in Italy (Table 2).

Differences in the characteristics of influenza $\mathrm{A}\left(\mathrm{H}_{3}\right)$ cases and controls are presented in Table 3.

Among 533 individuals for whom vaccination status was available, 179 (33.5\%) were vaccinated. The median time since vaccination was 105 and 74 days for cases and controls, respectively $(p=0.031)$.

The complete case analysis was done for 530 individuals after excluding those with missing information on $2011 / 12$ seasonal vaccination $(n=5)$, on hospitalisations for chronic disease in the previous year $(n=2)$ and on practitioners' visits in the previous year $(n=1)$. The crude VE against influenza $\mathrm{A}\left(\mathrm{H}_{3}\right)$ was 42.9 (95\% confidence interval ( $\mathrm{Cl}): 10.3$ to 63.6$)$ and the adjusted $43 \%$ (95\% Cl: -0.4 to 67.7 ) (Table 4).

\section{Discussion}

Our pooled early estimates suggest that the point estimate of the of the 2011/12 influenza vaccine against influenza $\mathrm{A}\left(\mathrm{H}_{3}\right)$ in the target group for vaccination was below $50 \%$. These results are consistent with the VE against influenza $\mathrm{A}\left(\mathrm{H}_{3}\right)$ estimated in Australia for the season $2011(58 \%, 95 \% \mathrm{Cl}:-53$ to 89$)$ [14] and with the Spanish early estimates of the 2011/12 VE against influenza $\mathrm{A}\left(\mathrm{H}_{3}\right)$ among target group for vaccination (54\%, 95\% Cl: 1 to 79$)$ [15].

\section{TABLE 2}

Participating practitioners and recruited influenza-like illness patients, by A(H3) influenza case-control status, vaccination status and study site, multicentre case-control study, study sites in eight European Union countries,

week 48/2011-week 7/2012

\begin{tabular}{|c|c|c|c|c|c|c|c|c|}
\hline \multirow[t]{2}{*}{$\begin{array}{l}\text { Study } \\
\text { site }\end{array}$} & \multirow[t]{2}{*}{$\begin{array}{l}\text { Number of } \\
\text { practitioners } \\
\text { participating } \\
\text { in the study }\end{array}$} & \multirow[t]{2}{*}{$\begin{array}{l}\text { Number of } \\
\text { practitioners } \\
\text { recruiting at } \\
\text { least one } \\
\text { ILI patient }{ }^{\mathrm{a}}\end{array}$} & \multirow[t]{2}{*}{$\begin{array}{l}\text { Number of } \\
\text { ILI patientsa } \\
\text { recruited by } \\
\text { practitioners }\end{array}$} & \multirow[t]{2}{*}{$\begin{array}{l}\text { Inclusion period for the } \\
\text { preliminary analysis } \\
\text { (ISO weeks) }\end{array}$} & \multicolumn{2}{|c|}{$\begin{array}{l}\text { Number of included ILI } \\
\text { patients positive for } \\
\text { influenza } \mathrm{A}\left(\mathrm{H}_{3}\right) \text { and } \\
\text { with known vaccination } \\
\text { status }\end{array}$} & \multicolumn{2}{|c|}{$\begin{array}{c}\text { Number of included ILI } \\
\text { patients negative for any } \\
\text { influenza and with known } \\
\text { vaccination status }\end{array}$} \\
\hline & & & & & Total & Vaccinated & Total & Vaccinated \\
\hline France & 499 & 169 & 325 & Week 52/2011-week 6/2012 & 4 & 1 & 24 & 12 \\
\hline Hungary & 94 & 63 & 354 & Week 49/2011-week 7/2012 & 2 & 0 & 112 & 41 \\
\hline Ireland & 28 & 11 & 60 & Week 50/2011-week 7/ 2012 & 5 & 4 & 3 & 3 \\
\hline Italy & 10 & 10 & 143 & Week 48/2011-week 7/2012 & 18 & 6 & 33 & 15 \\
\hline Poland & 35 & 15 & 45 & $\begin{array}{c}\text { Not included in preliminary } \\
\text { analysis (no influenza } \mathrm{A}_{3} \text { ) } \\
\text { cases) }\end{array}$ & o & & & \\
\hline Portugal & 59 & 30 & 149 & Week 51/2011-week 7/2012 & 23 & 5 & 47 & 24 \\
\hline Romania & 100 & 56 & 128 & Week 52/2011-week 7/2012 & 18 & 1 & 31 & 6 \\
\hline Spain & 231 & 174 & 886 & Week 52/2011-week 7/2012 & 136 & 37 & 77 & 24 \\
\hline Total & 1,056 & 528 & 2,090 & & 206 & 54 & 327 & 125 \\
\hline
\end{tabular}

ILI: influenza-like illness; ISO: International Organization for Standardization.

a ILI patients meeting the European Union case definition, swabbed less than eight days after onset of symptoms within the study period.

b From 15 days after the start of the vaccination campaign to week 7/2012; we excluded controls with an onset of symptoms in the weeks before the first influenza $\mathrm{A}\left(\mathrm{H}_{3}\right)$ case in the study site.

ILI patients in a vaccination target group included in the study, after excluding those with missing information on laboratory results, vaccination status or date of vaccination. 
Influenza $\mathrm{A}(\mathrm{H} 3)$ cases $(\mathrm{n}=208)$ and influenza-negative controls $(\mathrm{n}=330)$ in vaccination target groups recruited at study sites in seven European Union countries, by week of symptom onset, week 48/2011-week 7/2012

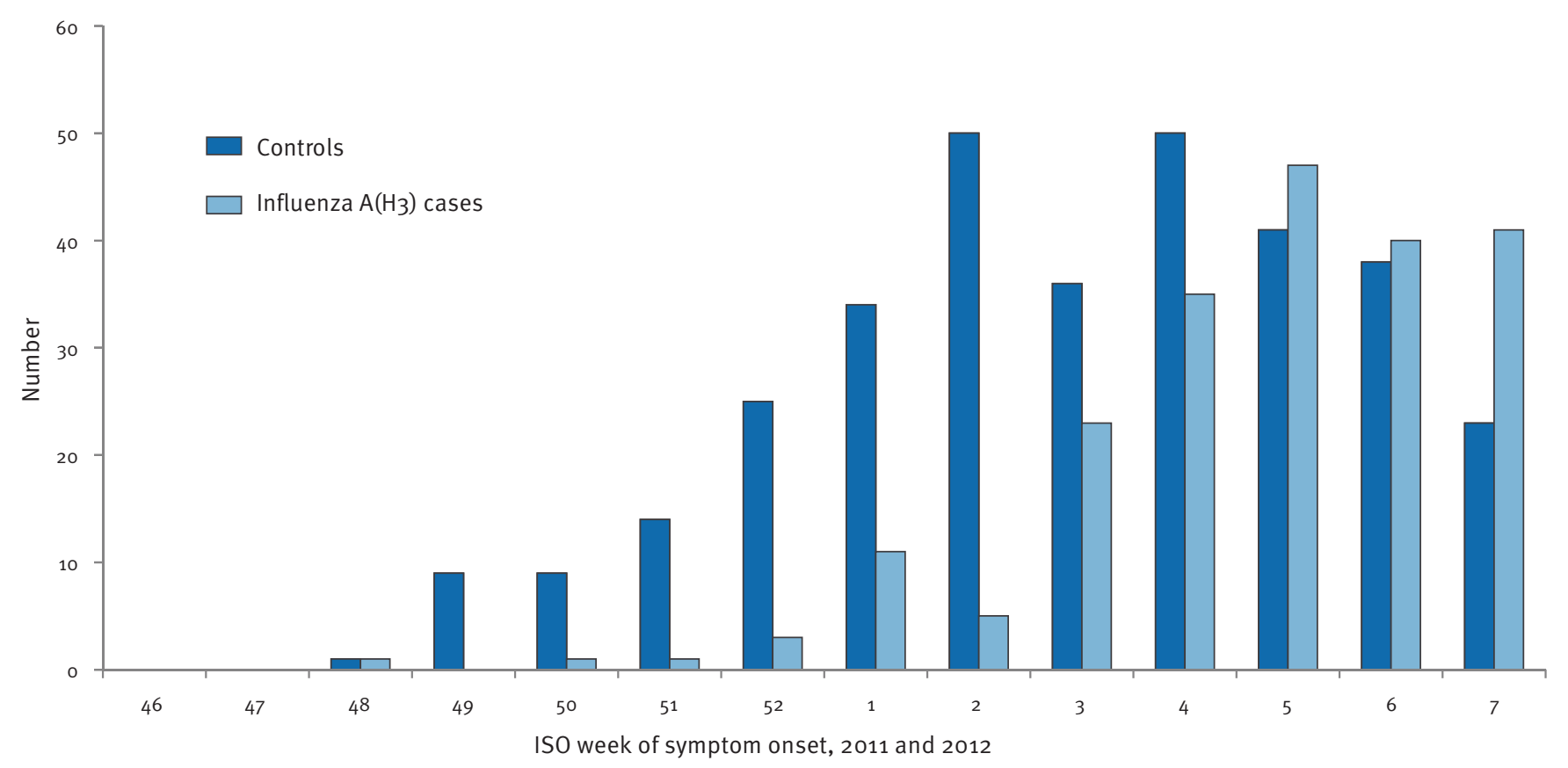

International Organization for Standardization (ISO) definition of a week.

The late start of the 2011/12 season in Europe [2] and the low influenza incidence in some of the eight countries participating in the multicentre case-control season limited the sample size for this preliminary analysis. By week 7/2012, four of the eight countries participating in the study had not reached the peak of the influenza season.

We included ILI patients swabbed less than eight days after symptom onset. Due to the small sample size we did not assess potential misclassification (false influenza $\mathrm{A}\left(\mathrm{H}_{3}\right)$-negatives because of late swabbing) by restricting the analysis to those swabbed less than four days after ILI onset. However, only $12 \%$ of the ILI patients included in this preliminary analysis were swabbed more than three days after onset of ILI symptoms (Table 2). This will be addressed in the final analysis.

There were important differences between target groups for vaccination and non-target groups (data not shown). The vaccine coverage was $2.8 \%$ in the non-target groups compared to $33.8 \%$ in the target groups and the median age was 26 years and 56 years respectively. In this preliminary analysis our results are restricted to the population for which the vaccine is recommended. We collected information on the main potential confounding factors described in the literature [16]. The crude and adjusted VE were similar, suggesting that within this subpopulation and using a specific laboratory-confirmed outcome, the presence of known confounding was minimised.
The low to moderate VE we observed may be explained by a limited match identified between the circulating influenza $\mathrm{A}\left(\mathrm{H}_{3}\right)$ virus strains and the vaccine strain [2]. In February 2012, the vaccine strain selection committee at the World Health Organization (WHO) concluded that there was evidence of increasing antigenic and genetic drift in circulating influenza $\mathrm{A}\left(\mathrm{H}_{3} \mathrm{~N}_{2}\right)$ and consequently recommended to include a different influenza $A\left(\mathrm{H}_{3}\right)$ vaccine strain in the $2012 / 13$ seasonal vaccine [17].

In the 2011/12 season, the time lag between the beginning of the vaccination campaigns and the start of the influenza season was longer than in previous seasons. In our preliminary analysis, the delay from vaccination to onset of symptoms was longer in cases than in controls. This may suggest that waning immunity has contributed to the moderate VE observed. However, with the sample available for this preliminary analysis, we could not verify this hypothesis.

Our preliminary estimates suggest that, among the target groups for vaccination, the effectiveness of the $2011 / 12$ influenza vaccine is low to moderate against medically-attended ILI confirmed as influenza $A\left(\mathrm{H}_{3}\right)$. At the end of the season, a larger sample size per study site may allow us to estimate also the VE against other influenza viruses, by age group, and to further explore hypotheses on the reasons for the low VE observed early in the season. 
TABLE 3

Characteristics of $A(H 3)$ influenza cases $(n=208)$ and test-negative controls $(n=330)$ in vaccination target groups included from study sites in seven European Union countries, week 48/2011-week 7/2012

\begin{tabular}{|c|c|c|c|}
\hline Characteristic & $\begin{array}{l}\text { Number of influenza cases/ } \\
\text { total } n(\%)^{\mathrm{a}}\end{array}$ & $\begin{array}{l}\text { Number of test-negative } \\
\text { controls/total } n(\%)^{\mathrm{a}}\end{array}$ & $P$ value \\
\hline Median age & 56.0 & 56.0 & $1.000^{\mathrm{b}}$ \\
\hline \multicolumn{4}{|l|}{ Age group (years) } \\
\hline $\begin{array}{l}0-4 \\
5-14 \\
15-64 \\
\geq 65 \\
\end{array}$ & $\begin{array}{c}6 / 208(2.9) \\
17 / 208(8.2) \\
115 / 208(55.3) \\
70 / 208(33.7)\end{array}$ & $\begin{array}{c}13 / 330(4.0) \\
10 / 330(3.2) \\
201 / 330(61.0) \\
106 / 330(32.1)\end{array}$ & $0.050^{c}$ \\
\hline Females & $117 / 208(56.3)$ & $208 / 330(53.6)$ & $0.124^{c}$ \\
\hline \multicolumn{4}{|l|}{ Symptoms } \\
\hline $\begin{array}{l}\text { Fever } \\
\text { Malaise } \\
\text { Headache } \\
\text { Myalgia }\end{array}$ & $\begin{array}{l}198 / 206(96.1) \\
194 / 202(96.0) \\
179 / 207(86.5) \\
185 / 207(89.4)\end{array}$ & $\begin{array}{c}293 / 320(89.1 .7) \\
277 / 304(91.1) \\
243 / 327(74.3) \\
258 / 327(78.9)\end{array}$ & $\begin{array}{l}0.003^{c} \\
0.033^{c} \\
0.001^{c} \\
0.002^{c}\end{array}$ \\
\hline \multicolumn{4}{|c|}{ Days between onset of symptoms and swabbing } \\
\hline $\begin{array}{l}0 \\
1 \\
2 \\
3 \\
\geq 4\end{array}$ & $\begin{array}{c}8 / 208(3.9) \\
74 / 208(35.6) \\
63 / 208(30.3) \\
44 / 208(21.2) \\
19 / 208(9.1)\end{array}$ & $\begin{array}{c}21 / 330(6.4) \\
113 / 330(34.2) \\
100 / 330(30.3) \\
48 / 330(14.6) \\
48 / 330(14.6)\end{array}$ & $0.101^{c}$ \\
\hline Seasonal influenza vaccination ${ }^{d}, 2011 / 12$ & $54 / 206(26.2)$ & $125 / 327(38.2)$ & $0.005^{c}$ \\
\hline Seasonal influenza vaccination, $2010 / 11$ & $50 / 206(24 \cdot 3)$ & $126 / 323(39.0)$ & $<0.001^{\mathrm{c}}$ \\
\hline Obese & $21 / 207(10.1)$ & $57 / 330(17.3)$ & $0.024^{\mathrm{c}}$ \\
\hline Heart diseases & $36 / 208(17.3)$ & $107 / 330(32.4)$ & $<0.001^{\mathrm{c}}$ \\
\hline At least one chronic disease & $121 / 208(58.2)$ & $254 / 330(77.0)$ & $<0.001^{\mathrm{c}}$ \\
\hline \multicolumn{4}{|l|}{ Smoker } \\
\hline $\begin{array}{l}\text { Current } \\
\text { Former } \\
\text { Never }\end{array}$ & $\begin{array}{c}30 / 202(14.9) \\
22 / 202(10.9) \\
150 / 202(74.3)\end{array}$ & $\begin{array}{c}49 / 302(16.2) \\
53 / 302(17.5) \\
200 / 302(66.2)\end{array}$ & $0.087^{\mathrm{c}}$ \\
\hline $\begin{array}{l}\text { Median number of practitioners' visits } \\
\text { in the previous } 12 \text { months }\end{array}$ & 4 & 5 & $0.031^{\mathrm{b}}$ \\
\hline $\begin{array}{l}\text { Any hospitalisation in the previous } 12 \\
\text { months for chronic diseases }\end{array}$ & $9 / 208(4 \cdot 3)$ & $23 / 327(7.0)$ & $0.262^{c}$ \\
\hline $\begin{array}{l}\text { Median number of days from vaccination } \\
\text { to onset of ILI symptoms }\end{array}$ & 105 & 74 & $\left\langle 0.001^{b}\right.$ \\
\hline
\end{tabular}

ILI: influenza-like illness.

a Unless otherwise indicated.

b Non-parametric test of the median.

c Two-sided Fisher's exact test.

d Vaccination more than 14 days before onset of ILI symptoms.

TABLE 4

Pooled crude $(n=530)$ and adjusted $(n=521)$ 2011/12 seasonal influenza vaccine effectiveness against laboratory-confirmed A(H3) influenza in target groups for vaccination at study sites in seven European Union countries, week 48/2011-week 7/2012

\begin{tabular}{|l|c|c|c|c|}
\hline Crude versus adjusted & Cases/controls & Vaccinated cases/controls & Vaccine effectiveness (\%) & 95\% confidence intervals \\
\hline Crude $^{\mathrm{a}}$ & $206 / 324$ & $54 / 123$ & 42.9 & 10.3 to 63.6 \\
\hline Adjusted model b, c $^{\mathrm{b}}$ & & & 43.0 & -0.4 to 67.7 \\
\hline
\end{tabular}

Study site included in the model as fixed effect.

b Model adjusted for presence of at least one chronic disease, sex, at least one hospitalisation for chronic disease in the previous 12 months, age group, practitioners' visits in the previous 12 months (0-1, 2-4 and $\geq 5$ visits) and week of symptom onset.

c Onset week 49 dropped due to no cases (nine records dropped). 


\section{Acknowledgements}

The I-MOVE network has been funded by the European Centre for Disease Prevention and Control (ECDC) since 2007.

We are grateful to all patients, practitioners and epidemiologists from the eight study sites who actively participated in the study. France: Isidore Grog (collective name of the Réseau des GROG network), Sylvie van der Werf, Bruno Lina, Martine Valette, Vincent Enouf, Dominique Rousset (National Reference Centre for Influenza virus France North and South), Astrid Vabret, Françoise Stoll Keller, Geneviève Giraudeau, Hervé Fleury, Laurent Andreoletti, Pierre Pothier (associated hospital laboratories).Marion Quesne, Françoise Barat, William Ouadi (Coordination team);

Hungary: Marta Melles, general director of National Center for Epidemiology, and staff of the Influenza Virus Laboratory, National Center for Epidemiology, Budapest; Brigitta Harkay Petrovicsné and Mónika Luib, Office of the Chief Medical Officer, Budapest; epidemiologists from the district and subregional public health offices; Ireland: Suzanne Cotter, Darina O'Flanagan, Health Protection Surveillance Centre, Dublin; Allison waters, NVRL; Italy: Enrico Volpe, Piero Borgia, Laziosanita' Agenzia di Sanita' Pubblica, Lazio Region; Roberto Rangoni, Alba Carola Finarelli Regional Health Autorities. Emilia-Romagna Region; Maria Luisa Tanzi, Regional Reference Laboratory Emilia-Romagna; Giuseppe Delogu, Regional Reference Laboratory, Lazio; Portugal: Carlos Matias Dias, José Marinho Falcão (retired), Department of Epidemiology, Instituto Nacional de Saúde Dr Ricardo Jorge, Lisbon; Associação Portuguesa de Médicos de Clínica Geral [Portuguese association of general practitioners]; Romania: Viorel Alexandrescu, George Necula, Maria Magdalena Mihai and laboratory technical staff, Cantacuzino National Institute of Research-Development for Microbiology and Immunology, Bucharest; Adriana Pistol, Rodica Popescu, National Centre for Surveillance and Control of Communicable Diseases, Bucharest; epidemiologists from sentinel Public Health Directorates Constanta, Dolj, Iasi, Maramures, Calarasi, Prahova, Mures, Tulcea, Galati, Bihor, Sibiu; Spain: Jesús Castilla and Manuel García Cenoz, Instituto de Salud Pública de Navarra, Navarra; CIBERESP; Virtudes Gallardo and Esteban Pérez, Servicio de Epidemiología y Salud Laboral. Secretaría General de Salud Pública y Participación. Consejería de Salud de Andalucía; Carolina Rodriguez and Tomás Vega, Dirección General de Salud Pública e Investigación, Desarrollo e Innovación, Consejería de Sanidad de Castilla y León; Carmen Quiñones and Eva Martinez, Servicio de Epidemiología, Subdirección de Salud Pública de La Rioja; Jaume Giménez and Juana M. Vanrell, Servicio de Epidemiología, Dirección General de Salut Pública, Baleares, Palma de Mallorca; CIBERESP; Daniel Castrillejo, Servicio de Epidemiología. Dirección General de Sanidad y Consumo, Consejería de Bienestar Social y Sanidad, Ciudad Autónoma de Melilla; Julián M. Ramos and Maria C. Serrano, Dirección General de Salud Pública, Servicio Extremeño de Salud, Junta de Extremadura.

\section{Members of the I-MOVE case-control studies team}

ECDC, Stockholm, Sweden: BC Ciancio, P Kramarz, A Nicoll; EpiConcept, Paris, France: E Kissling, A Moren, C Savulescu, M Valenciano; France: JM Cohen, A Mosnier, I Daviaud, TT Bui; Hungary: B Oroszi; J K Horváth, S Caini, M Rózsa; Ireland: J Rebolledo, A O`Malley,J O`Donnell, L Domegan, J Moran, S Coughlan, M Joyce; C Collins; Italy: C Rizzo, A Bella, M C Rota, S Giannitelli, S Puzelli, I Donatelli, S Declich; Poland: I P Stankiewicz, M Gluchowska, L Brydak, A.W.Kosek,D.Grzeganek; Portugal: B Nunes, A Machado, I Batista, R Guiomar, P Pechirra, P Gonçalves, P Conde, I Falcão; Romania: D Pitigoi, A E Ivanciuc, E Lupulescu; Spain:
S Jiménez-Jorge, S de Mateo, F Pozo, J Ledesma,I Casas, A Larrauri..

\section{References}

1. European Centre for Disease Prevention and Control (ECDC). European Influenza Surveillance Network (EISN). Stockholm: ECDC; 2010. Available from: http://www.ecdc.europa.eu/en/ activities/surveillance/eisn/pages/index.aspx

2. European Centre for Disease Prevention and Control (ECDC). Weekly influenza surveillance overview. Main surveillance developments in week $7 / 2012$ (13-19 February 2012). Stockholm: ECDC; 24 Feb 2012. Available from: http://ecdc. europa.eu/en/publications/Publications/120224_SUR_Weekly_ Influenza_Surveillance_Overview.pdf

3. Haut Conseil de la Santé Publique (HCPS). Le calendrier vaccinal et les recommandations vaccinales 201 selon l'avis du Haut Conseil de la Santé Publique. [2011 vaccination schedule and recommendations from the Haut conseil de la santé publique in France]. BEH 2011;10-11:103-20. [French]. Available from: http://www.invs.sante.fr/content/ download/4393/28810/version/4/file/beh_10_11_2011.pdf

4. Vacinaçao contra a gripe com a vacina trivalente na época 2011/2012 - Alargamento dos groupos de risco para vacinaçao gratuita. [Influenza vaccination with the trivalent vaccine in the season 2011/2012 - Extension of risk groups for free vaccinations]. Lisbon: Directorate General of Health; 27 Sep 2011. Portuguese. Available from: http://www.dgs.pt/ms/2/ default.aspx?id=5509

5. Metodologia de supraveghere a gripei, infectiilor acute respiratorii şi SARI pentru sezonul 2011-2012. [Methodology of surveillance of influenza, acute respiratory infections and SARI, season 2011-2012]. Bucarest: National Centre for Surveillance and Control of Communicable Diseases; 2012. Romanian. Available from: http://www.insp.gov. ro/cnscbt/index.php?option=com_docman\&task=doc download\&gid $=286 \&$ Itemid $=10$

6. Prevenzione e controllo dell'influenza: raccomandazioni per la stagione 2011-2012. [Prevention and control of influenza: recommendations for the season 2011-2012]. Roma: Ministero della Salute; 2012. Italian. Available from: http://www. normativasanitaria.it/normsan-pdf/0000/39451_1.pdf

7. Prevención de la gripe. Vacunación antigripal [Influenza prevention. Recommendations for influenza vaccination]. Madrid: Ministry of Health and Social Policy. [Accessed 12 Apr 2012]. Spanish. Available from: http://www.msps.es/ ciudadanos/enfLesiones/enfTransmisibles/gripe/gripe. htm\#prevencion

8. Program Szczepień Ochronnych na rok 2012. [Immunisation Programme for 2012]. Warsaw: Chief Sanitary Inspectorate; 2011. Available from: http://www.pis.gov.pl/userfiles/file/ Departament\%20EP/szczepienia/zal_szczep\%20PSO\%202012. pdf

9. Target groups for seasonal influenza vaccine 2011/2012 Ireland. Dublin: Health Protection Surveillance Centre; 2011 Available from: http://www.hpsc.ie/hpsc/A-Z/Respiratory/ Influenza/Seasonallnfluenza/Vaccination/File,12961,en.pdf

10. Az Országos Epidemiológiai Központ módszertani levele a 2011. évi védõoltásokról [The National Centre for Epidemiology methodological letter of the year 2011 on vaccinations]. Epinfo 2011;18. 21 Feb 2011. Hungarian. Available from: http://www. oek.hu/oek.web?nid=444\&pid=1

11. Valenciano M, Kissling E, Cohen IM, Oroszi B, Barret AS, Rizzo $C$, et al. Estimates of Pandemic Influenza Vaccine Effectiveness in Europe, 2009-2010: Results of Influenza Monitoring Vaccine Effectiveness in Europe (I-MOVE) Multicentre Case-Control Study. PLoS Med. 2011;8(1):e1000388.

12. European Commission. Commission Decision 2009/363/EC of 30 April 2009 amending Decision 2002/253/EC laying down case definitions for reporting communicable diseases to the Community network under Decision No 2119/98/EC of the European Parliament and of the Council. OJ L 110, 1.5.208, p. 58. 2011. Available from: http://eur-lex.europa.eu/LexUriServ/ LexUriServ.do?uri=0J:L:2009:110:0058:0059:EN:PDF

13. Kissling E, Valenciano M, I-MOVE case-control studies team. Early estimates of seasonal influenza vaccine effectiveness in Europe, 2010/11: I-MOVE, a multicentre case-control study. Euro Surveill. 2011;16(11): pii=19818. Available from: http:// www.eurosurveillance.org/ViewArticle.aspx?Articleld $=19818$ 
14. Fielding JE, Grant KA, Tran T, Kelly HA. Moderate influenza vaccine effectiveness in Victoria, Australia, 2011. Euro Surveill. 2012;17(11):pii=20115. Available from: http://www. eurosurveillance.org/ViewArticle.aspx?Articleld=20115

15. Jiménez-Jorge S, de Mateo S, Pozo F, Casas I, García Cenoz M, Castilla J, et al. Early estimates of the effectiveness of the 2011/12 influenza vaccine in the population targeted for vaccination in Spain. Euro Surveill. 2012;17(12): $\mathrm{pii}=20129$. Available from: http://www.eurosurveillance.org/ViewArticle. aspx?Articleld $=20129$

16. Valenciano M, Kissling E, Ciancio BC, Moren A. Study designs for timely estimation of influenza vaccine effectiveness using European sentinel practitioner networks. Vaccine. 2010;28(46):7381-8.

17. World Health Organization (WHO). Recommended composition of influenza virus vaccines for use in the 2012-2013 northern hemisphere influenza season.. Geneva: WHO: Feb 2012.

Available from: http://www.who.int/influenza/vaccines/virus/ recommendations/201202_recommendation.pdf 